\title{
DNA Sequencing Protocols
}




\section{Methods in Molecular Biology}

John M. Walker, SERIES EDITOR

23. DNA Sequencing Protocols, edited by Hugh G. Griffin and Annette M. Griffin, 1993

22. Microscopy, Optical Spectroscopy, and Macroscopic Techniques, edited by Christopher Jones, Barbara Mulloy, and Adrian $\mathrm{H}$. Thomas, 1993

21. Protocols in Molecular Parasitology, edited by John E. Hyde, 1993

20. Protocols for Oligonucleotides and Analogs, edited by Sudhir Agrawal, 1993

19. Biomembrane Protocols: I. Isolation and Analysis, edited by John M. Graham and Joan A. Higgins, 1993

18. Transgenesis Techniques, edited by David Murphy and David A. Carter, 1993

17. Spectroscopic Methods and Analyses, edited by Christopher Jones, Barbara Mulloy, and Adrian H. Thomas, 1993

16. Enzymes of Molecular Biology, edited by Michael M. Burrell, 1993

15. PCR Protocols, edited by Bruce A. White, 1993

14. Glycoprotein Analysis in Biomedicine, edited by Elizabeth F. Hounsell, 1993

13. Protocols in Molecular Neurobiology, edited by Alan Longstaff and Patricia Revest, 1992

12. Pulsed-Field Gel Electrophoresis, edited by Margit Burmeister and Levy Ulanovsky, 1992

11. Practical Protein Chromatography, edited by Andrew Kenney and Susan Fowell, 1992

10. Immunochemical Protocols, edited by Margaret M. Manson, 1992

9. Protocols in Human Molecular Genetics, edited by Christopher G. Mathew, 1991

8. Practical Molecular Virology, edited by Mary K. L. Collins, 1991

7. Gene Transfer and Expression Protocols, edited by Edward J. Murray, 1991

6. Plant Cell and Tissue Culture, edited by Jeffrey W. Pollard and John M. Walker, 1990

5. Animal Cell Culture, edited by Jeffrey W. Pollard and John M. Walker, 1990

4. New Nucleic Acid Techniques, edited by John M. Walker, 1988

3. New Protein Techniques, edited by John M. Walker, 1988

2. Nucleic Acids, edited by John M. Walker, 1984

1. Proteins, edited by John M. Walker, 1984 


\section{Methods in Molecular Biology • 23}

\section{DNA Sequencing Protocols}

Edited by

\section{Hugh G. Griffin and Annette M. Griffin}

Institute of Food Research, Norwich Research Park, Norwich, England

Humana Press 
(c) 1993 Humana Press Inc.

999 Riverview Drive, Suite 208

Totowa, New Jersey 07512

All rights reserved.

No part of this book may be reproduced, stored in a retrieval system, or transmitted in any form or by any means, electronic, mechanical, photocopying, microfilming, recording, or otherwise without written permission from the Publisher.

\section{Photocopy Authorization Policy:}

Authorization to photocopy items for internal or personal use, or the internal or personal use of specific clients, is granted by The Humana Press Inc., provided that the base fee of US $\$ 3.00$ per copy, plus US $\$ 00.20$ per page is paid directly to the Copyright Clearance Center at 27 Congress Street, Salem, MA 01970. For those organizations that have been granted a photocopy license from the CCC, a separate system of payment has been arranged and is acceptable to The Humana Press Inc. The fee code for users of the Transactional Reporting Service is: $[0-89603-248-5 / 93 \$ 3.00+\$ 00.20]$.

Printed in the United States of America. 980765432

Library of Congress Cataloging in Publication Data

Main entry under title:

Methods in molecular biology.

DNA sequencing protocols / edited by Hugh G. Griffin and Annette M. Griffin.

p. cm. -- (Methods in molecular biology ; 23)

Includes index.

ISBN 0-89603-248-5

1. Nucleotide sequence. I. Griffin, Hugh G. II. Griffin, Annette M.

III. Series: Methods in molecular biology (Totowa, NJ) ; 23.

[DNLM: 1. Sequence analysis, DNA. W1 ME9616J v. 23 1993 / QU 58 D62965 1993]

QP624.D634 1993

574.87'3282--dc20

NLM/DLC

for Library of Congress 


\section{Preface}

The purpose of DNA Sequencing Protocols is to provide detailed practical procedures for the widest range of DNA sequencing methods, and we believe that all the vanguard techniques now being applied in this fast-evolving field are comprehensively covered.

Sequencing technology has advanced at a phenomenal rate since the original methods were first described in the late 1970s and there is now a huge variety of strategies and methods that can be employed to determine the sequence of any DNA of interest. More recently, a large number of new and innovative sequencing techniques have been developed, including the use of such novel polymerases as Taq polymerase and Sequenase, the harnessing of PCR technology for linear amplification (cycle) sequencing, and the advent of automated DNA sequencers.

DNA sequencing is surely one of the most important techniques in the molecular biology laboratory. Sequence analysis is providing an increasingly useful approach to the characterization of biological systems, and major multinational projects are already underway to map and sequence the entire genome of organisms, such as Escherichia coli, Saccharomyces cerevisiae, Caenorhabditis elegans, and Homo sapiens. Most scientists recognize the importance of DNA sequence data and perceive DNA sequencing as a valuable and indispensable aspect of their work. Recent technological advances, especially in the area of automated sequencing, have removed much of the drudgery that was formerly associated with the technique, whereas innovative computer software has greatly simplified the analysis and manipulation of sequence data. Large-scale sequencing efforts, such as the Human Genome Project, produce the DNA sequences of many unknown genes. Such data provide an impetus for molecular biologists to produce probes and antibodies that can be used to identify the gene product, its cellular location, and its time of appearance in the 
developing cell. A function can be assigned by mutant analysis or by comparison of the deduced amino acid sequence with proteins of known function. In this way, DNA sequencing acts as a catalyst, stimulating future research into many diverse areas of science.

More than a quarter of DNA Sequencing Protocols is devoted to automated sequencing technology, while the other innovations, such as cycle sequencing, solid phase sequencing, chemiluminescent sequencing, and multiplex sequencing, are also fully covered. In addition, a large part of the book is devoted to basic sequencing techniques and individual chapters are dedicated to topics such as template preparation, sequencing reactions, gel pouring, and electrophoresis of reaction samples. There are also useful chapters on sequencing PCR products, lambda clones, plasmids, and cosmids.

Each contribution is written in a manner that will allow a competent scientist who is unfamiliar with the method to carry out the technique successfully at the first attempt by simply following the detailed practical procedures that have been described by the author. Any major problems or faults that can occur, the sources of the problems, and how they can be identified and overcome are clearly described. We hope that DNA Sequencing Protocols will provide precise instruction for the newcomer to DNA sequencing and present a wide range of new techniques to the experienced researcher.

The editors express their gratitude and appreciation to all who have helped produce this volume and in particular to the contributing authors.

Finally, we would like to dedicate this book to our own genetic recombinants, Jessica and Stephanie, with love.

Hugh and Annette Griffin 


\section{Contents}

Preface

Сн. 1. DNA Sequencing,

Hugh G. Griffin and Annette M. Griffin 1

$\mathrm{CH}$. 2. M13 Cloning Vehicles: Their Contribution to DNA Sequencing, Joachim Messing 9

CH. 3. Cloning into M13, Qingzhong $\mathbf{Y u}$

CH. 4. Transfection of $E$. coli with M13 DNA,

Fiona M. Tomley

Сн. 5. M13 Phage Growth and Single-Strand DNA Preparation,

Fiona M. Tomley

Сн. 6. M13 Phage Growth and DNA Purification

Using 96 Well Microtiter Trays, Alan T. Bankier

Сн. 7. Generation of Random Fragments by Sonication,

Alan T. Bankier

Сн. 8. Generation of a Nested Set of Deletions Using Exonuclease III, George Murphy.

Сн. 9. Sequential Deletions of Single-Stranded DNA:

"Cyclone Sequencing,"

George Murphy.

Сн. 10. Subcloning for DNA Sequencing,

Gary M. Studnicka, Shau-Ping Lei, Hun-Chi Lin, and Gary Wilcox

Сн. 11. Sequencing Using Custom Designed Oligonucleotides,

Ulrike Gerischer and Peter Dürre 75

CH. 12. Dideoxy Sequencing Reactions

Using Klenow Fragment DNA Polymerase I, Alan T. Bankier 83

CH. 13. Dideoxy Sequencing Reactions Using T7 Polymerase, Peter Dürre and Ulrike Gerischer

CH. 14. Dideoxy Sequencing Reactions Using Sequenase Version 2.0, Hugh G. Griffin and Annette M. Griffin 103 
Сн. 15. Dideoxy Sequencing Reactions Using Taq Polymerase,

Fabrizio Arigoni and P. Alexandre Kaminski

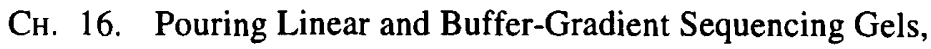

Paul Littlebury

CH. 17. Electrophoresis of Sequence Reaction Samples,

Alan T. Bankier

$\mathrm{CH}_{\text {H. 18. Plasmid Sequencing, }}$

Hugh G. Griffin and Annette M. Griffin

$\mathrm{CH}_{\mathrm{H}}$ 19. Plasmid Sequencing,

George Murphy.

Сн. 20. Direct Sequencing of Inserts Cloned into Lambda Vectors,

Afshan N. Malik

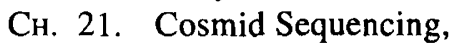

Molly Craxton.

Сн. 22. Genomic Sequencing,

Gerd P. Pfeifer and Arthur D. Riggs

CH. 23. Sequencing of Double-Stranded PCR Products,

Susannah Gal.

Сн. 24. Sequencing Double-Stranded Linear DNA

with Sequenase and $\left[\alpha-{ }^{35} S\right]$ dATP,

Jean-Laurent Casanova

CH. 25. Solid Phase PCR Sequencing of Biotinylated Products,

Andrew Green and Mark Vaudin

$\mathrm{CH}$. 26. Cycle Sequencing,

Robert W. Blakesley

CH. 27. Direct Blotting Electrophoresis,

Stephan Beck

CH. 28. Multiplex DNA Sequencing,

Stephan Beck

CH. 29. DNA Sequencing by Chemiluminescent Detection,

Stephan Beck

CH. 30. Reverse Sequencing of M13 Cloned DNA,

Alan T. Bankier

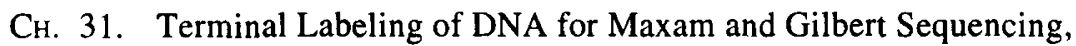
Eran Pichersky

CH. 32. DNA Sequencing by the Chemical Method,

Eran Pichersky

CH. 33. DNA Sequencing by Chemical Degradation Using One, Two, and Four Different Fluorophores,

André Rosenthal.

CH. 34. Linear Amplification Sequencing with Dye Terminators, André Rosenthal and D. Stephen Charnock-Jones. 
CH. 35. Sequencing Reactions for the Applied Biosystems 373A

Automated DNA Sequencer,

Nicolette Halloran, Zijin Du, and Richard K. Wilson

CH. 36. Sequencing Reactions for ALF (EMBL)

Automated DNA Sequencer,

Wilhelm Ansorge, Jürgen Zimmermann, Holger Erfle,

Neil Hewitt, Thomas Rupp, Christian Schwager,

Brian Sproat, Josef Stegemann, and Hartmut Voss

$\mathrm{CH}_{\mathrm{H}}$ 37. Sequencing Using the DuPont Genesis ${ }^{\mathrm{TM}} 2000$ DNA

Analysis System,

Len Hall

Сн. 38. The Use of Robotic Workstations in DNA Sequencing,

Alan T. Bankier 373

Index 385 


\section{Contributors}

Wilhelm ANSORge • European Molecular Biology Laboratory,

Heidelberg, Germany

Fabrizio Arigoni - Institut Pasteur, Paris, France

AlAN T. BANKIER • MRC Lab of Molecular Biology, Cambridge,

England

StEPHAN BeCK - Imperial Cancer Research Fund, London, England

ROBERT W. BLAKESLEY • Life Technologies, Inc., Gaithersburg, MD

JeAn-Laurent Casanova • Ludwig Institute for Cancer Research,

Epalinges, Switzerland

D. STEPHEN ChARNock-Jones • Cambridge University School

of Clinical Medicine, Cambridge, England

Molly Craxton • MRC Lab of Molecular Biology, Cambridge,

England

Zusin Du $\bullet$ Washington University School of Medicine, St. Louis, MO

Peter DürRe - Institut für Mikrobiologie, Georg-August-University,

Göttingen, Germany

Holger ERfLe • European Molecular Biology Laboratory,

Heidelberg, Germany

SusanNah GaL $-M S U-D O E$ Plant Research Lab, East Lansing, MI

ULRIKE GERISCHER - Institut für Mikrobiologie, Georg-August-University,

Göttingen, Germany

ANDREW GREEN - MRC Molecular Genetics Unit, Addenbrooke's

Hospital, Cambridge, England

ANNETte M. Griffin - Institute of Food Research, Norwich, England

HugH G. GRIFFIN • Institute of Food Research, Norwich, England

LEN HALL - University of Bristol School of Medical Science, Bristol,

England

Nicolette Halloran - Washington University School of Medicine,

St. Louis, $M O$ 
NeIL HewITT - European Molecular Biology Laboratory, Heidelberg, Germany

P. AleXANDRe Kaminski - Institut Pasteur, Paris, France

Shau-Ping LeI $\bullet X O M A$, Santa Monica, $C A$

Hun-Chi Lin $• X O M A$, Santa Monica, CA

Paul LitTlebury - Institute for Animal Health, Houghton Lab, Cambridgeshire, England

Afshan N. MaLiK - University of Wales, Cardiff, Wales

JoACHim Messing • Waksman Institute, Piscataway, NJ

GEORGE MuRPhy • JI Center for Plant Science Research, Norwich, England

GERD P. PFEIFER - Beckman Research Institute of the City of Hope,

Duarte, $C A$

ERAN PICHERSKY • University of Michigan, Ann Arbor, MI

ARTHUR D. RIGGS - Beckman Research Institute of the City of Hope,

Duarte, $C A$

ANDré Rosenthal - Cambridge University School of Clinical

Medicine, Cambridge, England

THомAs Rupp - European Molecular Biology Laboratory, Heidelberg,

Germany

CHRISTIAN SCHWAGER - European Molecular Biology Laboratory,

Heidelberg, Germany

BRIAN SPROAT - European Molecular Biology Laboratory, Heidelberg,

Germany

Josef StegemanN • European Molecular Biology Laboratory,

Heidelberg, Germany

GaRY M. STUdnICKa $-X O M A$, Santa Monica, $C A$

Fiona M. TOMLEY - Institute for Animal Health, Compton, England

MARK VAUDIN • MRC Molecular Genetics Unit, Addenbrooke's

Hospital, Cambridge, England

HaRTMut Voss - European Molecular Biology Laboratory,

Heidelberg, Germany

GARY WILCOX $-X O M A$, Santa Monica, California

RICHARD K. WILSON - Washington University School of Medicine,

St. Louis, $M O$

QINGZHONG YU • University of Alabama at Birmingham, Birmingham, $A L$ Jürgen ZimMERMANN - European Molecular Biology Laboratory,

Heidelberg, Germany 